UDC 811'111

DOI https://doi.org/10.32841/2409-1154.2020.46-1.48

\author{
Lazebna N. V., \\ Ph. D. in Philology, Associate Professor, \\ Assistant Professor at the Department of Theory and Practice of Translation \\ National University "Zaporizhzhia Polytechnic"
}

\title{
ENGLISH-LANGUAGE SENTENCE PROCESSING: DIGITAL TOOLS AND PSYCHOLINGUISTIC PERSPECTIVE
}

\begin{abstract}
Summary. The central interpretation of verbs depends on the construction and structuring of the perceptual space. The participants sensed the objects and phenomena described. Further, they correlated their perception with the surrounding reality. Then, they comprehended the information mentioned in the English-language sentences. At the final stage of their perception, they created their experience background and considered the process of knowledge formation and structuring. Verbalization of their ideas in certain sentences is under consideration. Therefore, tense is a link between a verb form and a period of time, which has to be described. On the one hand, there is a time-tense reference. Tense and time are related concepts. Grammatical categories represent related links in human speech and their perception of the surrounding. The main challenges of the speakers occur when the description of reality happens in terms of present and past tense verb forms.

Temporal parameters are the basic tools determining the future formation of the sentence. Temporal categories of the verb relate to the concept of time as a given reality or a known moment. Psycholinguists use self-paced sentence reading task to analyze the readers' response to different linguistic structures. The participant presses the button once he sees a word on the screen or one word at a time. When difficulties occur, the participant presses the button slower. Short reading times refer to preferences, but longer periods relate to the dispreferred meanings. Being limited by grammar, the learners of the English language may be unable to fully analyze the material they need to understand/consider, analyze. Cognitive mechanisms should be involved to make the learning process more effective and efficient. There is a need for an instant link occurring between language and thinking. Language is not an abstract phenomenon, and thoughtless learning of rules will hardly result in positive outcomes for learners.
\end{abstract}

Key words: word-by-word sentence processing, non-native speakers, verb tense, time perception, identification of spacetime ratio.

Introduction. Being limited by grammar, the learners of the English language may be unable to fully analyze the material they need to understand/consider, analyze, and so on. Cognitive mechanisms should be involved to make the learning process more effective and efficient. There is a need for an instant link occurring between language and thinking. Language is not an abstract phenomenon and thoughtless learning of rules will hardly result in positive outcomes for learners [4].

The goal of this paper is to analyze sentence word-by-word processing as an important stage in human cognition of language. This paper focuses on Past Simple/Future Simple tenses and differences in perception of these tenses. There is a need to differentiate the concepts 'time' and 'tense.' Tense "refers to the grammatical expression of the time of the situation described in the proposition, relative to some other time. This other time may be the moment of speech: e.g., the PAST and Future designate time before the moment of speech, respectively" [3]. The inflections, particles, or auxiliaries are specific linguistic tools, which help the speakers to choose tense.

Literature review. According to Jabarri, "Tense shows the time of the action or state being expressed by a verb" [3]. "Most SPR paradigms examine processing difficulties that arise during the reading of sentences that contain what could be classified as either an ambiguity, an anomaly, or a distance dependency. Ambiguities arise where the grammar permits two or more distinct syntactic interpretations of a word or phrase in the sentence and observable processing strategy often occurs when the (native) parser tends towards one interpretation over the other" [6]. Tremblay, Derwing, Libben, Westbury (2011) describe the effectiveness of word-by-word processing, and it is possible to correlate these findings with this study, where the perception of the sentences will depend on tenses.

We can see that time and tense are inconsistent concepts. "While time is a natural or notional concept of language, tense is the relationship between the form of the verb which expresses the time. There is not usually a one-to-one relationship between time and tense within a language" [3]. This claim donates our future hypothesis of the research. The readers read a sentence, then they create a relevant picture in their heads. If the readers see the Present Simple Tense verb form, they will think about the present time. Further, they will understand time meant in the sentence (after translation, words/tense analysis, or grammar/semantic analysis).

According to current researches and studies, there are different perceptions of time/events in the present/future. Thus, a group of researchers, "explored how imagining a situation of getting acquainted with someone in the near future led people to estimate the action's target as highly familiar, but when the event was presented in the distant future, participants evaluated the target as less familiar" [1]. The study conducted by Connor and Smith shows that there are two variants of the considered present. "TRA suffers from the drawbacks that it is inconsistent with a plausible account of the transparency of perception and inconsistent with a common-sense conception of the mind-independence of that which is perceived. The Minimal Account is immune to these concerns" [2]. These conclusions may explain the differences in the participants' perceptions of the present. At this point, they may come across incongruences of future time representation. Perceive, anticipate, and remember, - these stages may refer to the perception of reality.

If to correlate these attitudes of humans to verb use, it is relevant to refer to the study by Marsden, Thompson, Plonsky, (2018) "self-paced reading has been a general term that includes several different formats. First, the display can be cumulative, meaning once a stimulus segment is revealed it remains visible to the par- 
ticipant as the next segment is revealed and the next and so on, until the entire sentence is finally displayed all together, or noncumulative, meaning only one segment is visible at a time and every time a new segment is revealed the previous one is re-masked" [6]. Lutfullina (2015) also underlines the key importance of tenses in sentence perception and reflection [5].

They should be aware of what they learn, first of all.

Changing tenses, describing the same time, or a moment, in reality, should be comprehensible for the learners. It is relevant to offer a certain algorithm of tenses cognition, analysis, and reflection.

1. A time-determinant factor, which helps to understand the moment described in the sentence.

2. A content-determinant factor describing the essence of the sentence and its message.

Thus, if a person says what he knows for sure, then, he speaks about the present time. I know that I go there every day.

If he speaks about some plans, intentions, and he does not know for sure what he is talking about, then he can speak about the future time. In both of these cases, individuals still can use Present Simple/ Future Simple to describe future actions, but they use Present Simple to describe actions, situations at a given present moment.

Future Simple tense refers to the structural knowledge of the speaker, but it does not relate to his instant experience, observations, or facts he knows for sure. From this perspective, it is relevant to build a sentence word by word and perceive it in a similar way to cognize the Future Simple tense appropriately. When using Future Simple tenses, the speaker refers to his suggestions, suppositions, and possible ideas, because he cannot know for sure will anything happen or not. Don't go there late at night. You will be robbed!

This sentence reflects a supposition of the speaker. These are his subconscious fears, ideas, suggestions, which do not have any factual basis. He describes unseen things. These are his guess about the future. This is a description of a non-existent situation.

There is also another suggestion related to Future Simple representation. Someone is ringing at the door. I'll open it.

In this sentence, the verb will describe the future intention of the speaker, but it relates to a given moment. This is also a reflection of intentions, interpretation of the structural knowledge related to the future. Moreover, the absence of factual evidence is another factor, which differs Future Simple from Present Simple. The majority of polite questions start with the verb will. What will you do there next time? Where will we go for a vacation? All of these questions reflect ambiguous information.

When the learners use the Future simple, they may also describe characteristics common for one or another individual. She'll always keep silence. This is also a reflection of typical behavior or repetition of certain situations several times.

Sometimes, we use Future Simple to reflect our expectations based on previous events/facts/information, and so on. There is, of course, a challenging overlapping of Present Simple/Future Simple in some cases. For example, This sportsman knows that he is the winner and will play the next year in this tournament. This sentence conveys the expectations about the future time, but in the given moment, now, this sportsman is the winner. This is a condition, which predetermines his participation in the future tournament. Therefore, there are numerous aspects of using Future Simple. The explanation of this tense is also a challenging issue. The perception of sentences in the Present Simple / Future Simple tenses also depends on various factors, which influence the meaning of the sentences.

Methodology

The central interpretation of verbs used depends on the construction and structuring of the perceptual space. The participants sensed the objects and phenomena described. Further, they correlated their perception with the surrounding reality. Then, they comprehended the information mentioned in the sentences. At the final stage of their perception, they, supposedly, created their experience background and considered the process of knowledge formation and structuring. Verbalization of their ideas and their concluding in certain sentences are under consideration of further experiments. Temporal parameters are the basic tools determining the future formation of the sentence [7]. Temporal categories of the verb relate to the concept of time as a given reality or a known moment. Psycholinguists use this self-paced sentence reading task to analyze the readers' response to different linguistic structures. With the help of a self-paced sentence reading task available online, the participant presses the button once he sees a word on the screen or one word at a time. When difficulties occur, the participant presses the button slower. Short reading times refer to preferences, but longer periods relate to the dispreferred meanings [8].

Results and discussion. The representation of present/future time with the help of verb forms. Word-by-word processing of sentences in these two different tenses may be rather difficult. For example,

1) These negotiations are on Dec. 8th (Present Simple).

2) My bus goes to Z-town in 4 hours (Present Simple).

3) This airplane will depart in five hours (Future Simple).

4) She will talk about it the next week (Future Simple).

In these examples, different tenses may refer to one time (for example, the future time). All 4 sentences describe the situation in the future, but we use different tenses to describe them. This section focuses on two participants and their self-paced sentence reading task of the abovementioned sentences. Supposedly, the participants will interpret the time described in the sentences using Present Simple, or preferred sentences. The region times of ambiguity can be the same for both participants. Supposedly, it is easier for the Participants to interpret the sentences in Present Simple rather than use Future Simple tense.

Table 1 underlines a close relationship of the ambiguous areas (amb $=321.1$ for preferred sentences with verbs in Present Simple and 335.0 for dispreferred sentences with Future Simple verb forms) for participant 1 . The processor reflected differences in the ambiguous areas when the participant focused on the verb tense (amb $1=347.0$ for the preferred verb tense choice and 353.1 for the dispreferred verb forms) \& (amb 2=389.2 for preferred meanings and 467.0 for dispreferred verb forms). These results from the first participant seem consistent with the expectations.

Table 1

Shows the results obtained from subject 1

\begin{tabular}{|l|c|c|c|}
\hline \multicolumn{1}{|c|}{ Participant 1 } & Amb & Amb 1 & Amb 2 \\
\hline Preferred sentences & 321.1 & 347.0 & 389.2 \\
\hline Dispreferred sentences & 335.0 & 353.1 & 467.0 \\
\hline
\end{tabular}

Table 2 shows times of reading of the sentences with Present Simple/Future Simple tenses for participant 2. Data obtained are similar. The area of ambiguity is almost the same for both participants 
(amb $=315.1$ for preferred verb tense (Present Simple) and 325.1 for dispreferred verb forms). Participant 2 showed a higher level of consequent word perception following verb forms ( $a m b 1=427.2$ for the preferred verbs and 368.4 for the dispreferred meanings). The higher indicator relates to a higher level of the dispreferred sentences (389.5) than the preferred sentences (356.3).

Table 2

Shows the results obtained from subject 2

\begin{tabular}{|l|c|c|c|}
\hline \multicolumn{1}{|c|}{ Participant 2 } & Amb & Amb 1 & Amb 2 \\
\hline Preferred sentences & 315.1 & 327.2 & 356.3 \\
\hline Dispreferred sentences & 325.1 & 368.4 & 389.5 \\
\hline
\end{tabular}

Both participants showed similar results and they have a similar area of ambiguity.

This experiment has some limitations and in the future, it is relevant to involve more participants and consider Eye-TrackingWhile-Reading experiments.

The participants interpreted their perception of verb tenses in the following way. ization

The sensor signal/perception of the sentence- goal- verbal-

1) Present time

Something happens here/there/exists and so on.

2) Future time

The time of the action has not come yet.

The choice of the verb forms can be interpreted in the following way:

1) Present tense: the verb form reflects current changes, processes happening at a given moment.

2) Future tense: the verb form shows that the action happens after the moment of speaking.

The processing memory of the participants can be described as follows:

1) Present Indefinite: uncertain, unsettled, unclear; in other words, with no definition of time, but something that happens.

2) Future Indefinite: uncertain, unsettled, unclear; in other words, with no definition of time, but something that happened after the moment of speaking.

To discuss the mechanisms of sentence formation, one of the most important things is to perceive the fact, which describes a certain situation or activity, and so on. The modes of perception are directly related to the mechanisms of ideas verbalization in language. The differences between the perception of time and further use of Present Simple/Future Simple in terms of the experiments show that time/tense perception is a process with different stages. In this research, it is interesting to process the perception of sentences both in the Present Simple and Future Simple tenses. It is appropriate to reveal and calculate the differences in perception of time described in the sentences using various verb forms.

\section{References:}

1. How verb tense affects the construal of action: The simple past tense leads people into an abstract mindset. Psicologica : revista de metodologia y psicologia experimental / P. Carrera et al. 2014. № 35 (2). P. 209-223.
2. Connor A., Smith J. The Perceptual Present. The Philosophical Quarterly. 2019. № 69 (277). P. 817-837. URL: https://doi.org/ $10.1093 / \mathrm{pq} / \mathrm{pqz} 017$

3. Jabarri J. Time and Tense in Language. International Journal of Linguistics. 2013. № 5 (5). P. 1948-5425.

4. Jegerski J. Self-paced reading. In J. Jegerski \& B. VanPatten (Eds.), Research methods in second language psycholinguistics. New York : Routledge, 2014.

5. Lutfullina G. Representation of the perception situation by English Tenses. Vestnik Tomskogo gosudarstvennogo universiteta. Filologiya. 2015. № 34. P. 23-32.

6. Marsden T., Plonsky L. A Methodological Synthesis of Self-Paced Reading in Second Language Research: Methodological synthesis of SPR tests. Applied Psycholinguistics. 2018. № 861-904. P. 1469-1817. URL: https://doi.org/10.1017/S0142716418000036

7. Self-Paced Reading Procedure. URL: https://www.hlp.rochester.edu/ resources/BCS152-Tutorial/SPRProcedure.html

8. Processing Advantages of Lexical Bundles: Evidence from Self-paced Reading and Sentence Recall Tasks / A. Tremblay et al. 2011.

Лазебна Н. В. Послівна обробка англомовного речення: технічні засоби та психолінгвістичний аспект

Анотація. Статтю присвячено вивченню послівної обробки англомовного речення неносіями англійської мови. Спираючись на теоретичний грунт та використовуючи технічні засоби, можливим видається співвідношення сприйняття людиною дійсності та її вираження в мові. Використання граматичних категорій, їх кореляція 3 когнітивними та психолінгвальними факторами сприятиме кращому розумінню процесу сприйняття англійської мови людиною. Тлумачення дієслів залежить від структурування перцептивного простору. Мовці зазвичай відчувають предмети та явища, які описуються, і співвідносять своє сприйняття 3 навколишньою дійсністю. Учасники цього дослідження намагалися покроково зрозуміти англомовні речення, використовуючи онлайн-інструментарій, та можливим видається кореляція психолінгвальних особливостей неносіїв англійської мови в побудові та використанні англомовних речень. Часові та просторові зв'язки $є$ визначаючими факторами при побудові англомовних повідомлень. Граматичні категорії представляють зв'язки в мовленні людини та характеризують сприйняття ними навколишнього середовища та оточення. Основні труднощі під час побудови речень виникають, коли опис реальності відбувається 3 використанням англомовних дієслівних форм теперішнього та минулого часу.

Часові параметри є основними інструментами, що визначають майбутнє формування речення. Часові категорії дієслова стосуються поняття часу як даної реальності чи відомого моменту. Психолінгвісти використовують експеримент із самостійного читання речень для аналізу реакції читачів при використанні різних граматичних структур. Сприйняття та аналіз мовного матеріалу слід розглядати із залученням не лише граматичних категорій, а і студій когнітивістики та психолінгвістики. Таким чином, необхідно проводити зв'язки між мовою та мисленням, зважати на специфіку сприйняття інформації мовцями.

Ключові слова: послівна обробка речень, носії мови, часова форма дієслова, сприйняття часу, ідентифікація співвідношення простору та часу. 